\title{
Compelled testing for the novel coronavirus
}

Testing for SARS-CoV-2 has been one of the main discussion points around the pandemic. Initially, a big issue was the lack of availability and accessibility of test kits worldwide. ${ }^{[1,2]}$ Burundi was in the news for a comment by a whistleblowing doctor - now disputed by the country's minister of health - explaining their low infection rate by reference to an absolute lack of testing. ${ }^{[3,4]}$ Several hard-hit countries have internal voices blaming late and inadequate measures, including a delay in widespread testing, for the severe impact of COVID-19 on healthcare systems. ${ }^{[5]}$

But the pendulum swings. The focus has shifted to scaling up tests as an indispensable component of an appropriate state response. ${ }^{[6,7]}$ The African Union Commission and the Africa Centres for Disease Control and Prevention launched the Partnership to Accelerate COVID-19 Testing (PACT) to facilitate at least 10 million tests in African Union countries with the least capacity. ${ }^{[8,9]}$ In South Africa (SA), more than 28000 health workers have been deployed with the goal of screening at least 1 in 10 South Africans. ${ }^{[10]}$ With mass testing being rolled out in SA, health workers will be faced with a new challenge: opposition. ${ }^{[11]}$

During the early days of the pandemic, people were already refusing to be quarantined, and some even refused to be tested. ${ }^{[12]}$ This rejection has been spurred on by fake news about tests being unsafe. ${ }^{[13]}$ Question marks surrounding tests have even been raised by heads of state, with the president of Tanzania publicly denouncing the quality of tests received after claims that a sample of a papaya and a goat tested positive. ${ }^{[14]}$ It seems likely that distrust in tests and authorities will continue.

It is therefore important for healthcare workers to understand when and how they can compel an individual to undergo a novel coronavirus test.

\section{Compelled testing: General position}

In an everyday situation, every person is free to choose whether to undergo a medical procedure such as a test. This choice forms part of their constitutionally protected right to privacy and their right to bodily integrity. ${ }^{[15]}$ However, rights can be limited, so even outside of the extraordinary circumstances presented by COVID-19, compelled testing is permitted in certain instances, such as the management of notifiable conditions and communicable diseases.

Compelled testing in SA is governed by the Regulations Relating to the Surveillance and the Control of Notifiable Medical Conditions (standard regulations). ${ }^{[16]}$ These regulations provide that the required mandatory medical examination ... must be determined on a case by case basis and tailored depending on the public health risk and individual circumstances of the person in question'. When someone refuses consent to be tested or treated, an application must be made to a High Court for an appropriate court order to legally compel the test. Until such time as a court order can be obtained, a 'health care provider should with the assistance of law enforcement agencies, subject a person who is a clinical or laboratory confirmed case, carrier or contact of a notifiable medical condition to prophylaxis, treatment or implement isolation or quarantine procedures whilst awaiting the court ... in order to prevent transmission'. However, before this step can be taken, the following conditions must be satisfied: the condition must pose a public health risk; and the person must have refused voluntary measures to protect public health, did not consent, and has been offered, and encouraged to accept, counselling to understand the nature of the voluntary measures, the personal health risk, the public health risk and the procedure that will be followed should he or she refuse voluntary measures.

\section{Compelled testing: SARS-CoV-2}

Compelled testing for SARS-CoV-2 is not governed by the standard regulations, because the outbreak of COVID-19 resulted in declaration of a State of Disaster. The Minister of Cooperative Governance and Traditional Affairs was therefore empowered to make regulations or issue directions on a wide range of issues including to prevent an escalation of the disaster, or to alleviate contain and minimise the effects of the disaster. ${ }^{[17]}$ On 18 March 2020, just such regulations were put into force (disaster management regulations). ${ }^{[18]}$ The disaster management regulations spoke to instances where members of the public refused testing. They provide that 'no person ... who is suspected of having contracted COVID-19, or who has been in contact with a person who is a carrier of COVID-19, may refuse consent to an enforcement officer for ... submission of that person to a medical examination, including but not limited to the taking of any bodily sample by a person authorised in law to do so. Where a person does refuse consent, an enforcement officer must apply to a magistrate for a warrant to compel such testing. The magistrate has to use a reasonable suspicion test, to determine whether or not to grant a warrant.

Here one can see how the disaster management regulations are less onerous than the standard regulations: firstly, magistrate's courts are geographically more widespread and numerous than High Courts, so it is easier to obtain a magistrate's consent than a High Court order; the standard regulations also require more individual safeguards; and the requirement of counselling is not present during a state of disaster.

\section{What about mass compelled testing?}

While compelled testing certainly forms part of our legal framework, it requires a case-by-case analysis (even under the disaster management regulations) and an element of judicial control. This approach may be functional when just a handful of persons are opposed to testing. However, should larger pockets of the community refuse to be tested, this approach could become impractical and costly. In this eventuality, the state should consider an amendment to current regulations, or a new regulation entirely, to practically cater for mass compelled testing.

One possible change that could prove resource-efficient and save time would be to allocate the decision-making power away from magistrates to health workers. This situation is not unprecedented. For the purposes of criminal investigation, a registered medical practitioner attached to any hospital is empowered take a blood sample or cause such a sample to be taken (which could include forceful measures) if they have reasonable grounds to believe that the contents of the blood of any person admitted to such hospital for medical attention or treatment may be relevant at any later criminal proceedings. ${ }^{[19]}$ In SA, the so-called DNA Act ${ }^{[20]}$ also allows specially trained police officers - without immediate judicial oversight - to take non-invasive DNA samples from arrested persons and convicted offenders. Anyone who is suspected of committing a crime, and all convicted offenders, will therefore be expected to give DNA samples to a specially designated police officer on request. ${ }^{[2]}$

Another possible solution would be to remove the case-specific consideration in each case, but to bring back the procedural safeguards 
in the standard regulations: counselling and an explanation of the procedure to compel testing in an effort to co-opt consent.

\section{Conclusions}

Can a healthcare worker compel someone to undergo a novel coronavirus test? Yes, but only after obtaining a warrant from a magistrate and on a case-by-case basis. To authorise compelled testing on a more widespread basis will require new regulations or an amendment of the current disaster management regulations.

Acknowledgements. Thank you to Safura Abdool Karim for allowing me to pick her brain on these issues and making helpful suggestions.

Funding. The research reported in this publication was partly supported by the South African Medical Research Council.

\section{Petronell Kruger}

PRICELESS SA: SAMRC/Wits Centre for Health Economics and Decision Science, School of Public Health, Faculty of Health Sciences, University of the Witwatersrand, Johannesburg, South Africa krugerpetronell@gmail.com

1. Davis R. Testing, testing, 123: Unpacking the confusion around SA's Covid-19 testing. Daily Maverick, 19 March 2020. https://www.dailymaverick.co.za/article/2020-03-19-testing-testing-123-unpacking the-confusion-around-sas-covid-19-testing/ (accessed 9 April 2020).

2. Kuenssberg L. Coronavirus: Lack of testing becomes political problem. BBC News, 1 April 2020 https://www.bbc.com/news/uk-politics-52118781 (accessed 16 April 2020)

3. Sowetan Live. In Africa, six nations seem so far to be spared Covid-19. 31 March 2020. https://www. sowetanlive.co.za/news/africa/2020-03-31-in-africa-six-nations-seem-so-far-to-be-spared-covid-19/ (accessed 10 April 2020)

4. Human Rights Watch. Burundi: Any COVID-19 cover-up will put lives at risk. 31 March 2020. https://www.hrw.org/news/2020/03/31/burundi-any-covid-19-cover-will-put-lives-risk (accessed 17 April 2020)

5. Shear MD, Goodnough A, Kaplan S, Sheri Fink S, Thomas K, Weiland N. The lost month: How a failure to test blinded the U.S. to Covid-19. New York Times, 28 March 2020. https://www.nytimes. com/2020/03/28/us/testing-coronavirus-pandemic.html (accessed 17 April 2020).
6. Winning A. South Africa needs 'hundreds of thousands' of COVID-19 tests - Health Minister. Reuters, 2 April 2020. https://www.cnbcafrica.com/news/2020/04/02/south-africa-needs-hundredsof-thousands-of-covid-19-tests-health-minister/ (accessed 3 April 2020).

7. Allen D. The best way out of this pandemic is to massively scale up testing. Here's how to do it. . Allen D. The best way out of this pandemic is to massively scale up testing. Here's how to do it.
Washington Post, 10 April 2020. https://www.washingtonpost.com/opinions/2020/04/10/best-wayout-this-pandemic-is-massively-scale-up-testing-heres-how-do-it/ (accessed 17 April 2020).

8. Africa Centres for Disease Control and Prevention. AU and Africa CDC launch partnership to accelerate COVID-19 testing: Trace, test and track. Press release, 21 April 2020. https://africacdc.org/ news/african-union-and-africa-centres-for-disease-control-and-prevention-launch-partnership-toaccelerate-covid-19-testing-trace-test-and-track/ (accessed 5 May 2020).

9. Fabricius P. Africa scrambles to ramp up Covid-19 testing. Daily Maverick, 28 April 2020. https://www. dailymaverick.co.za/article/2020-04-28-africa-scrambles-to-ramp-up-covid-19-testing (accessed 5 May 2020).

10. Cotterill J. South Africa's mass screening helps stem the coronavirus tide. Financial Times, 5 May 2020. https://www.ft.com/content/98d0d7c6-9bfb-4a64-bcab-19e0854a3b4d (accessed 6 May 2020).

11. Nortier C. As mass testing is rolled out, South Africa launches Covid-19 treatment trial. Daily Maverick, 2 April 2020. https://www.dailymaverick.co.za/article/2020-04-02-as-mass-testing-is-rolled-
out-south-africa-launches-covid-19-treatment-trial/ (accessed 3 April 2020).

12. Njilo N. Covid-19: Refusing to quarantine or self-isolate could land you in jail for a decade. Sunday Times, 18 March 2020. https://www.timeslive.co.za/news/south-africa/2020-03-18-covid-19-refusing-
Tilo to-quarantine-or-self-isolate-could-land-you-in-jail-for-a-decade/ (accessed 4 April 2020).

13. Grobler R. FAKE NEWS: No, Covid-19 testing kits are not contaminated. News24, 6 April 2020. https://www.news $24 . c 0 m / S o u t h A f r i c a / N e w s / f a k e-n e w s-n o-c o v i d-19$-testing-kits-are-notcontaminated-20200406 (accessed 7 April 2020).

14. Coronavirus: Tanzania testing kits questioned after goat and papaya test positive. SkyNews, 4 May 2020. https://news.sky.com/story/coronavirus-tanzania-testing-kits-questioned-after-goat-and-papayatest-positive-11982864 (accessed 6 May 2020).

15. South Africa. Constitution of the Republic of South Africa. 1996. https://www.gov.za/documents/ constitution-republic-south-africa-1996 (accessed 3 April 2020).

16. South Africa. National Health Act No. 61 of 2003. Regulations: Relating to the Surveillance and the Control of Notifiable Medical Conditions. Government Gazette No. 40945, 2017. (Published under Government Notice 604.) https://www.gov.za/sites/default/files/gcis_document/201706/40945gon604. pdf (accessed 3 April 2020).

pdf (accessed 3 April 2020).
17. South Africa. Disaster Management Act No. 57 of 2002. http://www.cogta.gov.za/cgta_2016/wpSouth Africa. Disaster Management Act No. 57 of 2002. http://www.cogta.gov.za/cgta
content/uploads/2016/06/DISASTER-MANAGEMENT-ACT.pdf (accessed 3 April 2020).

18. South Africa. Disaster Management Act No. 57 of 2002. Regulations: Disaster Management. Government Gazette No. 43107, 2020. (Published under Government Notice 318.) https://www.gov. za/sites/default/files/gcis_document/202003/43107gon318.pdf (accessed 3 April 2020).

19. South Africa. Criminal Procedure Act No. 51 of 1977. https://www.justice.gov.za/legislation/acts/1977051.pdf (accessed 4 April 2020).

20. South Africa. Criminal Law (Forensic Procedures) Amendment Act No. 37 of 2013. https://www.gov. za/documents/criminal-law-forensic-procedures-amendment-act-0 (accessed 4 April 2020).

S Afr Med J 2020;110(7):570-571. https://doi.org/10.7196/SAMJ.2020.v110i7.14890 